\title{
Analysis of Pathogenic Variants in BRCA1 and BRCA2 Genes using Next-Generation Sequencing in Women with Triple Negative Breast Cancer from South India
}

\section{Taruna Rajagopal}

Shanmugha Arts Science Technology \& Research Academy: Shanmugha Arts Science Technology and Research Academy

\section{Arun Seshachalam}

Dr.G.V.N Cancer Institute

\section{Arunachalam Jothi}

Shanmugha Arts Science Technology \& Research Academy: Shanmugha Arts Science Technology and Research Academy

\section{Krishna Kumar Rathnam}

Meenakshi Mission Hospital and Research Centre

\section{Srikanth Talluri}

Dana-Farber Cancer Institute

\section{Sivaramakrishnan Venkatabalasubramanian}

SRMIST: SRM Institute of Science and Technology

\section{Nageswara Rao Dunna ( $\nabla$ dnrao@biotech.sastra.edu )}

Shanmugha Arts Science Technology and Research Academy School of Chemical and Biotechnology https://orcid.org/0000-00015870-1035

\section{Research Article}

Keywords: Triple-negative breast cancer (TNBC), BRCA1, BRCA2, Pathogenic variants.

Posted Date: August 23rd, 2021

DOl: https://doi.org/10.21203/rs.3.rs-813826/v1

License: @ (i) This work is licensed under a Creative Commons Attribution 4.0 International License. Read Full License

Version of Record: A version of this preprint was published at Molecular Biology Reports on January 12th, 2022. See the published version at https://doi.org/10.1007/s11033-022-07129-2. 


\section{Abstract}

The frequency of triple-negative breast cancer (TNBC) incidence varies among different populations, suggesting the involvement of genetic component towards TNBC development. Previous studies have reported that $B R C A 1 / 2$ germline mutations confer a lifetime risk of developing TNBC. However, there is hardly any information regarding the common pathogenic variants (PVs) in BRCA1/2 genes that contribute to TNBC in the Indian population. Hence, we screened for PVs in BRCA1/2 and their association with clinico-pathological features in TNBC patients. Among the 59 TNBC genomic DNA samples sequenced, $8 B R C A$ mutations were detected in 59 TNBC patients (13.6\%). Almost 50\% pre-menopausal TNBC patients had a BRCA mutation. Of the 8 BRCA mutations, we observed BRCA7 mutations in 6 TNBC patients, and BRCA2 mutations in 2 TNBC patients. Among the 6 BRCA1 mutations, three were c.68_69delAG (185delAG) mutation. Remarkably, all the TNBC patients with $B R C A$ mutations exhibited higher-grade tumors (grade 2 or 3 ). However, among the $B R C A$ mutation carriers, only one patient with a BRCA2 mutation (p.Glu1879Lys) developed metastasis in the observed cohort. Our data advocates that South Indian women with higher grade TNBC tumors and without hereditary breast and ovarian cancer should be considered for $B R C A$ mutation screening, thereby enabling enhanced decision-making and preventive therapy.

\section{Introduction}

In women, the three most common cancers are breast, lung and colorectal cancer, where breast cancer (BC) alone contributes to $30 \%$ of female cancers [1]. BC accounted for an estimated 2.1 million cancer cases in 2018 and is the fifth leading cause of death globally [2, 3]. Triple-negative breast cancers (TNBC) is an aggressive BC subtype that lacks the expression of estrogen receptors (ER), progesterone receptors (PR) and have minimum or no HER2 protein expression [4]. TNBC accounts for $10-15 \%$ of BC, which is more likely to affect younger premenopausal women and present as poorly differentiated advanced-stage tumors [5]. TNBC is common among African Americans (AA) and intermediate between White/Caucasian Americans (WA) and West Africans, suggesting a correlation between African ancestry and TNBC [6]. TNBC incidence ranged from 6.7-27.9\% in different countries, however India reported the highest TNBC percentage (27.9\%) compared to other countries [7]. There are numerous clinical studies on TNBC incidence in African and Caucasian women, which documented TNBC to be more prevalent in African women. However, concerning TNBC incidence, India was found to be ahead of Africa, and the age at TNBC diagnosis was found to be 40-55 years in Indian women compared to 50-70 years in women from other countries [7]. The higher rate of TNBC incidence in India is due to various prominent risk factors such as deprivation status, obesity, lifestyle, high mitotic indexes, family history and $B R C A 1$ mutations. BRCA1 and BRCA2 are crucial tumor suppressor genes and mutations in $B R C A$ genes play a pivotal role in the development of TNBC and hereditary breast and ovarian cancer syndrome (HBOC) [8, 9]. It has been reported that approximately $70 \%$ of breast tumors in BRCA1 mutation carriers and around $16-23 \%$ of breast tumors in BRCA2 mutation carriers resulted in TNBC [10]. Initially, the National Comprehensive Cancer Network (NCCN) guidelines have suggested germline $B R C A 1 / 2$ testing for $\mathrm{BC}$ patients of young age ( $\leq 45$ years), male breast cancer, bilateral breast cancer and HBOC [11]. However, the recent NCCN guidelines have additionally included TNBC patients as an eligibility criteria for genetic testing [12]. Earlier studies have established the association of BRCA1/2 mutations with elevated cancer risk in Ashkenazi Jewish and European women [13-15]. Moreover, a recent study identified that BRCA1/2 mutations were associated with prolonged survival in women with TNBC but not in non-TNBC women [16]. There exists a wide variation in the BRCA1/2 mutational landscape and frequency with respect to ethnicity and geographical background. Ashkenazi Jewish [17, 18], Polish [19], Slovenian [20] and Icelandic [21] populations were identified to have relatively high frequency of $B R C A 1 / 2$ founder mutations. However, in India very few studies [22-26] have investigated the germline BRCA1/2 PVs in early-onset BC patients and HBOC. The exact germline mutational burden conferred by PVs in the Indian sub-continent is largely unknown, due to unaffordability and lack of awareness. Moreover, there is scarcity of information regarding the common PVs in BRCA1/2 that contributes to TNBC phenotype in the Indian population. It is crucial to identify the PVs for better characterization of TNBC in India, and for genetic counseling. Hence, the present screened for BRCA1 and BRCA2 gene mutations in TNBC patients from South India using next-generation sequencing (NGS) technology.

\section{Patients And Methods}

Patients: The study recruited TNBC patients from Dr.G.V.N Cancer Institute, Tamil Nadu. All the patients were histopathologically proven breast carcinomas. Women with metachronous breast cancer, hormone and/or Her2 positive breast cancers, and/or ovarian cancer were excluded from the study. Blood, clinical, and demographic data were collected from 59 TNBC patients, who consented to take part in the study. $3-5 \mathrm{ml}$ of venous blood was collected in a EDTA-K2 coated sterile vacutainers from patients through antecubital venepuncture. Informed consent was obtained from the participants. The study was in accordance with declaration of Helsinki and the ethical committee of Dr.G.V.N Cancer Institute approved the present study (GVNCIIEC: ECR/436/INST/TN/2013). 


\section{Methods}

The genomic DNA was isolated from the peripheral blood lymphocytes of TNBC cases. DNA isolation was performed within three days of sample collection using a commercially available HiPurA SPP blood DNA isolation kit (HiMedia ${ }^{\mathrm{T}}$, Mumbai, India) following the manufacturer's instructions. The quality of the isolated genomic DNA was assessed by performing agarose gel electrophoresis. Quantification of genomic DNA was performed by spectrophotometric analysis by using NanoDrop 2000 ${ }^{\text {TM }}$ spectrophotometer (Thermo Fischer Scientific, USA). This was followed by DNA purification, and DNA quality control (QC). All the 59 samples were quantified using Qubit ds DNA BR Assay kit (Invitrogen, Cat\# Q32850). DNA purity was checked using QIAxpert and DNA integrity was assessed on 1\% agarose gel electrophoresis. The entire BRCA1 $(81.2 \mathrm{~kb})$ and $B R C A 2(84.8 \mathrm{~kb})$ genes were sequenced in all the 59 TNBC samples. All the 59 QC passed samples were taken for the Library preparation and targeted capture. 100ng of the DNA was taken for the library preparation using KAPA HyperPrep Kit (Roche, Cat\# KK8504). The DNA samples were fragmented to produce 250bp inserts. The DNA fragments were then end repaired, 3 ' mono-adenylated, and ligated with indexed adapters. The adapter-ligated fragments were amplified with adapterspecific primers followed by size selection and purification to generate a genomic DNA library. Biotin-labelled probes were customdesigned to capture all the introns and the exons of the BRCA1 and BRCA2 genes. The probes were hybridized with the genomic DNA library for 16 hours at $65^{\circ} \mathrm{C}$. Post incubation, the hybridized libraries were captured using Streptavidin beads followed by stringent washes to remove unbound DNA molecules. The enriched libraries were then amplified and purified. The final libraries were assessed for fragment size distribution using TapeStation 4200 (Agilent, USA). The prepared libraries were quantified using Qubit dsDNA High Sensitivity Assay kit (Invitrogen, Cat\# Q32851). The obtained libraries were pooled and diluted to the final optimal loading concentration before cluster amplification on the Illumina flow cell. Once the cluster generation is completed, the cluster flow cell is loaded on the lllumina HiSeq $X$ instrument to generate 150bp paired-end reads of 100X (mean coverage). Bioanalyzer plots were used at each step to evaluate the library step, and qPCR was used for measuring the library quantity before sequencing. The generated sequence data was analyzed after necessary quality control for variant calling and variant annotation. The essential computational methods such as quality analysis (FASTQC), adapter trimming (fastmcq), alignment with human reference genome hg19 (BWA, Sentioen), duplicate removal (Picard), realignment and recalibration (GATK), variant calling, and variant annotation (VariMat and ANNOVAR) were performed on the raw FASTQ data. The identified $B R C A 1$ and $B R C A 2$ variants were compared with CDNA sequences of BRCA1 and BRCA2.

\section{Results}

The present study recruited 59 TNBC cases for investigating the prevalence and type of $B R C A$ mutations in South Indian women. All the samples which were sequenced passed the initial quality control. Among the 59 TNBC genomic DNA samples sequenced, we identified 8 $B R C A$ mutations in 59 TNBC patients (13.6\%). Among the 8 mutations, we observed BRCA1 mutations in 6 TNBC patients, and BRCA2 mutations were observed among 2 TNBC patients. Among all the BRCA1 and BRCA2 mutations identified in the present study, most of the mutations were classified as pathogenic by the ClinVar, except for a BRCA2 mutation which was identified as a benign variant by the ClinVar database. The age distribution of TNBC patients with BRCA mutations is represented in Fig. 1. BRCA1 mutations were observed in all age groups, in contrast to $B R C A 2$ mutations which were observed frequently in women with the age group of 40-50 years. The mean age of TNBC onset in $B R C A 1$ mutation carriers was $48.3 \pm 10.4$ years and that of $B R C A 2$ mutation carriers was $45 \pm 5.7$ years. Table 1 summarizes the type of $B R C A 1$ and $B R C A 2$ mutations observed in TNBC patients recruited in the present study. 
Table 1

$B R C A 1$ and BRCA2 mutations in TNBC patients of South India

\begin{tabular}{|c|c|c|c|c|c|c|c|c|c|c|}
\hline $\begin{array}{l}\text { Patient } \\
\text { Id }\end{array}$ & $\begin{array}{l}\text { BRCA1/2 } \\
\text { Mutation }\end{array}$ & rs ID & Ref. & Alt. & $\begin{array}{l}\text { Exonic/ } \\
\text { Intronic }\end{array}$ & $\begin{array}{l}\text { Mutation } \\
\text { Type }\end{array}$ & $\begin{array}{l}\text { Mutation } \\
\text { (Designation) }\end{array}$ & ClinVar & $\begin{array}{l}\text { Age } \\
\text { at } \\
\text { onset } \\
\text { (yrs.) }\end{array}$ & $\begin{array}{l}\text { Reports } \\
\text { from } \\
\text { South } \\
\text { India }\end{array}$ \\
\hline $\begin{array}{l}\text { GTNBC } \\
02\end{array}$ & BRCA1 & rs62625308 & G & A & Exon 11 & Stop Gain & $\begin{array}{l}\text { c.3607C > T } \\
\text { (p.Arg1203Ter) }\end{array}$ & Pathogenic & 55 & Yes \\
\hline $\begin{array}{l}\text { GTNBC } \\
06\end{array}$ & $B R C A 1$ & rs80358027 & C & $A$ & Splicing & - & $\begin{array}{l}\text { c. } 4357+1 G \text { > T } \\
(\text { IVS13 + 1G > T ) }\end{array}$ & Pathogenic & 55 & No \\
\hline $\begin{array}{l}\text { GTNBC } \\
32\end{array}$ & $B R C A 1$ & rs80357914 & CT & - & Exon 2 & $\begin{array}{l}\text { Frameshift } \\
\text { deletion }\end{array}$ & $\begin{array}{l}\text { c.68_69delAG } \\
\text { (p.Glu23ValfsTer17) }\end{array}$ & Pathogenic & 50 & Yes \\
\hline $\begin{array}{l}\text { GTNBC } \\
40\end{array}$ & $B R C A 1$ & rs80357914 & CT & - & Exon 2 & $\begin{array}{l}\text { Frameshift } \\
\text { deletion }\end{array}$ & $\begin{array}{l}\text { c.68_69delAG } \\
\text { (p.Glu23ValfsTer17) }\end{array}$ & Pathogenic & 31 & Yes \\
\hline $\begin{array}{l}\text { GTNBC } \\
48\end{array}$ & $B R C A 1$ & rs80357234 & G & $A$ & Exon 6 & Stop Gain & $\begin{array}{l}\text { c. } 220 \mathrm{C}>\mathrm{T} \\
\text { (p.Gln74Ter) }\end{array}$ & Pathogenic & 58 & No \\
\hline $\begin{array}{l}\text { GTNBC } \\
59\end{array}$ & $B R C A 1$ & rs80357914 & CT & - & Exon 2 & $\begin{array}{l}\text { Frameshift } \\
\text { deletion }\end{array}$ & $\begin{array}{l}\text { c.68_69delAG } \\
\text { (p.Glu23ValfsTer17) }\end{array}$ & Pathogenic & 41 & Yes \\
\hline $\begin{array}{l}\text { GTNBC } \\
11\end{array}$ & BRCA2 & rs80359531 & CT & - & Exon 11 & $\begin{array}{l}\text { Frameshift } \\
\text { deletion }\end{array}$ & $\begin{array}{l}\text { c.5718_5719CT } \\
\text { (p.Leu1908fs) }\end{array}$ & Pathogenic & 41 & No \\
\hline $\begin{array}{l}\text { GTNBC } \\
15\end{array}$ & BRCA2 & rs55996097 & G & $A$ & Exon 11 & $\begin{array}{l}\text { Missense } \\
\text { variant }\end{array}$ & $\begin{array}{l}\text { c. } 5635 G \text { > A } \\
\text { (p.Glu1879Lys) }\end{array}$ & Benign & 49 & No \\
\hline
\end{tabular}

A frameshift deletion c.68_69delAG mutation (p.Glu23ValfsTer17) located in the exon 2 of the BRCA1 gene was observed commonly in TNBC patients. The c.68_69delAG mutation, also called as 185delAG mutation occurred in three out of six BRCA1 mutation carriers (50\%). Other deleterious BRCA1 pathogenic variants observed in the TNBC patients were stop gain (c.3607C > T; p.Arg1203Ter and c.220C > T; p.GIn74Ter) and splicing variant (c.4357 + 1G > T; aka IVS13 + 1G > T) mutations. Among the two BRCA2 mutations, we observed a TNBC patient carrying a frameshift deletion mutation in the exon 11 of the BRCA2 gene (c.5718_5719CT; p.Leu1908fs) and another patient carrying a benign missense variant in exon 11 (c.5635G > A; p.Glu1879Lys). We did not observe any novel BRCA mutations in the investigated population. The clinicopathological characteristics of TNBC patients with $B R C A$ mutation are represented in Table 2 . BRCA mutations were observed in $50 \%$ of pre-menopausal TNBC patients. Remarkably, all the TNBC patients with $B R C A$ mutations exhibited higher-grade tumors (grade 2 or 3 ). Among all the BRCA mutation carriers, only one patient with a $B R C A 2$ mutation (missense variant; p.Glu1879Lys) developed metastasis in the observed cohort. Another interesting observation made in the present study is that among the eight patients with TNBC, one patient (GTNBC 02) with BRCA1 pathogenic variant (p.Arg1203Ter) developed ovarian cancer during the course of breast cancer treatment. Invasive ductal carcinoma was observed in most of the patients with $B R C A$ mutations. Moreover, TNBC patients with BRCA2 mutations developed advanced-stage tumors (Table 2). 
Table 2

Clinicopathological features of TNBC patients with BRCA mutations

\begin{tabular}{|c|c|c|c|c|c|c|c|c|c|}
\hline $\begin{array}{l}\text { Patient } \\
\text { Id }\end{array}$ & $\begin{array}{l}B R C A 1 / 2 \\
\text { Mutation }\end{array}$ & BMI & $\begin{array}{l}\text { Menopausal } \\
\text { status }\end{array}$ & $\begin{array}{l}\text { Tumor } \\
\text { Grade }\end{array}$ & $\begin{array}{l}\text { Tumor } \\
\text { Stage }\end{array}$ & LVI & Metastasis & HPE report & Position \\
\hline $\begin{array}{l}\text { GTNBC } \\
02\end{array}$ & BRCA1 & Overweight & $\begin{array}{l}\text { Post- } \\
\text { menopausal }\end{array}$ & 2 & II & Positive & No & $\begin{array}{l}\text { Invasive } \\
\text { ductal } \\
\text { carcinoma }\end{array}$ & $\begin{array}{l}\text { Left } \\
\text { breast }\end{array}$ \\
\hline $\begin{array}{l}\text { GTNBC } \\
06\end{array}$ & $B R C A 1$ & Normal & $\begin{array}{l}\text { Post- } \\
\text { menopausal }\end{array}$ & 3 & IV & Positive & No & $\begin{array}{l}\text { Invasive } \\
\text { ductal } \\
\text { carcinoma }\end{array}$ & $\begin{array}{l}\text { Left } \\
\text { breast }\end{array}$ \\
\hline $\begin{array}{l}\text { GTNBC } \\
11\end{array}$ & BRCA2 & Overweight & $\begin{array}{l}\text { Pre- } \\
\text { menopausal }\end{array}$ & 3 & III & Positive & No & $\begin{array}{l}\text { Invasive } \\
\text { ductal } \\
\text { carcinoma }\end{array}$ & $\begin{array}{l}\text { Right } \\
\text { breast }\end{array}$ \\
\hline $\begin{array}{l}\text { GTNBC } \\
15\end{array}$ & BRCA2 & Normal & $\begin{array}{l}\text { Post- } \\
\text { menopausal }\end{array}$ & 2 & IV & Positive & Yes & $\begin{array}{l}\text { Invasive } \\
\text { ductal } \\
\text { carcinoma }\end{array}$ & $\begin{array}{l}\text { Right } \\
\text { breast }\end{array}$ \\
\hline $\begin{array}{l}\text { GTNBC } \\
32\end{array}$ & BRCA1 & Obese & $\begin{array}{l}\text { Pre- } \\
\text { menopausal }\end{array}$ & 2 & IV & Positive & No & $\begin{array}{l}\text { Papillary } \\
\text { carcinoma }\end{array}$ & $\begin{array}{l}\text { Right } \\
\text { breast }\end{array}$ \\
\hline $\begin{array}{l}\text { GTNBC } \\
40\end{array}$ & BRCA1 & Normal & $\begin{array}{l}\text { Pre- } \\
\text { menopausal }\end{array}$ & 3 & I & Absent & No & $\begin{array}{l}\text { Medullary } \\
\text { carcinoma }\end{array}$ & $\begin{array}{l}\text { Right } \\
\text { breast }\end{array}$ \\
\hline $\begin{array}{l}\text { GTNBC } \\
48\end{array}$ & BRCA1 & Underweight & $\begin{array}{l}\text { Post- } \\
\text { menopausal }\end{array}$ & 2 & ॥ & Absent & No & $\begin{array}{l}\text { Invasive } \\
\text { ductal } \\
\text { carcinoma }\end{array}$ & $\begin{array}{l}\text { Left } \\
\text { breast }\end{array}$ \\
\hline $\begin{array}{l}\text { GTNBC } \\
59\end{array}$ & BRCA1 & Overweight & $\begin{array}{l}\text { Pre- } \\
\text { menopausal }\end{array}$ & 3 & I & Absent & No & $\begin{array}{l}\text { Invasive } \\
\text { ductal } \\
\text { carcinoma }\end{array}$ & $\begin{array}{l}\text { Left } \\
\text { breast }\end{array}$ \\
\hline
\end{tabular}

\section{Discussion}

The contribution of $B R C A 1$ and $B R C A 2$ mutations that predispose to triple-negative breast cancer development in Indian women is largely unexplored. Thus, there is an urgent necessity for population-specific studies to understand the underlying pathogenic variants that contribute to TNBC development in South Indian women. Hence, the present study screened the entire BRCA1 and BRCA2 genes for pathogenic variants in 59 TNBC patients using NGS. In the current study, 6 BRCA1 mutations were identified in TNBC patients. The most common BRCA1 pathogenic variant was c.68_69delAG (p.Glu23ValfsTer17) mutation, which was observed in three out of six BRCA ${ }^{M u t}$ positive TNBC patients. Among the three c.68_69delAG (also known as 185delAG) mutation-positive TNBC cases, two patients were observed to have a positive family history of cancer. Reports globally suggest that the frequency of $B R C A 1$ and $B R C A 2$ mutations vary widely across different ethnicities and geographic regions. The presence of this deleterious variant in the Indian population was first identified in a South Indian family from Trivandrum [27]. Later, two South Indian families from Kerala [23] and two sisters from Goa [28] were reported to have 185delAG mutation. A previous South Indian study by Vaidyanathan et al. [25] explored the role of BRCA1/2 mutations in hereditary breast and ovarian (HBOC) cases in South India. They observed $28 \%$ BRCA mutations in HBOC patients $(24.6 \%$ $B R C A 1^{M u t}$ and $3.3 \% B R C A 2^{\text {Mut }}$ ). In line with our reports, they observed the presence of $B R C A 1^{\text {Mut }}$ in all age groups; however, $B R C A 2^{\text {Mut }}$ was observed only in women with $\leq 40$ years of age. Similarly, they also observed a higher occurrence of 185delAG BRCA7 (frameshift deletion) mutation in South Indian women. Remarkably, the 185delAG mutation is the founder mutation of the Ashkenazi Jewish (AJ) population and is responsible for the development of HBOC in AJ women. Besides, North Indian [24] and North-East Indian [29] studies also reported the presence of 185delAG mutation in breast cancer patients (non-Jewish ancestry) with no family history of cancer. Similarly, this mutation was also observed in the non-Jewish American population [30]. Interestingly, the 185 delAG mutation was reported to have developed around 61 generations ago and arose independently not less than twice in the non-Jewish population [31]. Notably, Drost et al. [32] reported that tumors of both murine and breast cancer cell line with BRCA1185stop and BRCA1185delAG mutations, respectively, expressed a new domain-less BRCA1 (RING-less) protein that mediates resistance to homologous recombination deficiency (HRD) therapies. Hence, investigation of 185delAG mutation in South Indian women might have better clinical and public health connotations. Moreover, the Indian population is not a completely uni-ethnic population, and it has a high prevalence of conservative mating habits, which prevailed for numerous generations. Thus, the likelihood of founder mutations cannot be entirely ruled out in such a population [33]. 
The other BRCA1 ${ }^{M u t}$ observed in a TNBC patient of the present study is the c.3607C > T (p.Arg1203Ter) mutation, which results in BRCA1 protein truncation. This mutation was reported in a North Indian study by Mehta et al. [34], and was observed in two patients with ovarian cancer. Similarly, another Indian study observed the prevalence of the Arg1203Ter mutation in both breast and ovarian cancer patients, irrespective of family history of cancer [35]. Remarkably, in line with our observation, this variation was also reported in Turkish TNBC patients [36]. Besides, this mutation was previously reported in Italian women with breast and/or ovarian cancer [37]. We also observed a splicing variant (c.4357 + 1G > T; IVS13 + 1G > T) in one of the TNBC patients. We did not find any Indian study reporting this variant; however, Ahmad et al. [35] reported a nearby intronic variant (c.4357 $+2 T>G)$ in a North Indian breast cancer patient. Nevertheless, c. $4357+1 G>T$ intronic variant was reported in breast cancer patients from Latvia [38], China [39], mixed ethnicity [40], Brazil [41], and America [42]. Moreover, Lindor et al. [43] had classified this variant under the class 5 variant. Individuals carrying class 5 BRCA1 variant should be considered as a carrier of completely pathogenic mutation and genetic testing should be recommended for all the at-risk relatives. Similarly, we observed the c. $220 \mathrm{C}>\mathrm{T}$ (p.GIn74Ter) $B R C A 7^{M u t}$ in a TNBC patient. Interestingly, this variant was recently reported in a TNBC patient from North India [44]. This variant was also reported in Chinese breast cancer patients [39].

Regarding the BRCA2 variants observed in the present study, one patient was observed to carry the BRCA2 c.5718_5719CT (p.Leu1908fs) pathogenic variant. This variant was reported in a male breast cancer patient recruited in the UNCseq ${ }^{\text {TM }}$ study. The patient had a family history of cancer, where his sister and paternal aunt were affected with breast cancer [45]. This is a class 4 variant (likely-pathogenic) and genetic testing is recommended for at-high risk relatives. Moreover, this BRCA2 variant was also observed in an Italian ovarian cancer patient resistant to platinum therapy [46]. This variant was also reported in two Chinese breast cancer patients [39, 47], Algerian HBOC patients [48], Macedonian [49], and German [50] breast cancer patients. The other BRCA2 variant observed in the present study is the c.5635G > A (p.Glu1879Lys) missense variant. Even though this variant has been categorized under class 2 (likely not pathogenic) mutation, Zuntini et al. [51] observed several families with BRCA2 Glu1879Lys variant. Moreover, a report by Thirthagiri et al. [52] observed the presence of Glu1879Lys missense variant in an Indian breast cancer patient. Interestingly, the WECARE study by Borg et al. [53] reported the presence of BRCA2 Glu1879Lys variant in contralateral breast cancer patients. Pertaining to the clinical characteristics of TNBC patients with BRCA mutation, similar to our observation Thirthagiri et al. [52] observed invasive ductal carcinoma as the prevalent histological breast cancer subtype in both BRCA1 and BRCA2 mutation carriers. They also reported that all of the BRCA mutant tumors were mostly grade II or III, and none of them were grade I tumors. Furthermore, in agreement with our report, several studies observed the higher prevalence of BRCA1 mutant tumors in TNBC patients [52, 54]. Strikingly, Lang et al. [39] reported that Chinese women with $B R C A$ mutations are at reduced risk of developing breast cancer, suggesting the effect of specific BRCA mutations and ethnic background in modulating breast cancer risk. Noteworthily, for BRCA1/2 mutation detection, NGS confers a comparably accurate and rapid yield compared to Sanger sequencing [55]. This might help the clinicians to make much informed and timely treatment decisions, such as usage of PARP inhibitors; thereby, increasing the survival of TNBC patients. Up to our knowledge, this is the first study to perform $B R C A$ mutation screening in TNBC patients, without hereditary breast and ovarian cancer in South India. Hence, our study suggests that BRCA1 mutation testing could be incorporated for South Indian women diagnosed with TNBC, particularly for patients with a family history of cancer

\section{Declarations}

Funding: This study was funded by the Department of Science and Technology, SERB - Government of India (YSS/2015/001692) and Oncoclub, Chennai.

\section{Conflict of interest: None}

Author Contributions: TR: Data curation, Formal analysis, Investigation, Methodology, Writing - original draft, Writing - review \& editing. AS: Methodology, Resources, Supervision. AJ: Data analysis, Validation, Software. KKR: Methodology, Resources. ST: Investigation, Supervision, Review \& editing; SV: Review \& editing; NRD: Conceptualization, Funding acquisition, Project administration, Resources, Investigation, Validation, Supervision, Writing - review \& editing.

Ethical approval Study proceeded with the approval of ethical committee Dr. GVN cancer Institute (GVNCIIEC - ECR/436/INST/TN/2013) Informed Consent: Informed consent was obtained from all the individual participants included in the study.

\section{References}

1. Siegel RL, Miller KD, Jemal A (2020) Cancer statistics, 2020. CA Cancer J Clin 70:7-30 
2. Bray F, Ferlay J, Soerjomataram I, Siegel RL, Torre LA, Jemal A (2018) Global cancer statistics 2018: GLOBOCAN estimates of incidence and mortality worldwide for 36 cancers in 185 countries. CA Cancer J Clin 68:394-424

3. Global Burden of Disease Cancer Collaboration, Fitzmaurice C, Akinyemiju TF, Al Lami FH, Alam T, Alizadeh-Navaei R et al (2018) Global, Regional, and National Cancer Incidence, Mortality, Years of Life Lost, Years Lived With Disability, and Disability-Adjusted LifeYears for 29 Cancer Groups, 1990 to 2016: A Systematic Analysis for the Global Burden of Disease Study. JAMA Oncol 4:1553-1568

4. Bauer KR, Brown M, Cress RD, Parise CA, Caggiano V (2007) Descriptive analysis of estrogen receptor (ER)-negative, progesterone receptor (PR)-negative, and HER2-negative invasive breast cancer, the so-called triple-negative phenotype: a population-based study from the California cancer Registry. Cancer 109:1721-1728

5. Ray M, Polite BN (2010) Triple-negative breast cancers: a view from 10,000 feet. Cancer J 16:17-22

6. Jiagge E, Jibril AS, Chitale D, Bensenhaver JM, Awuah B, Hoenerhoff M et al (2016) Comparative Analysis of Breast Cancer Phenotypes in African American, White American, and West Versus East African patients: Correlation Between African Ancestry and Triple-Negative Breast Cancer. Ann Surg Oncol 23:3843-3849

7. Thakur KK, Bordoloi D, Kunnumakkara AB (2018) Alarming Burden of Triple-Negative Breast Cancer in India. Clin Breast Cancer 18:e393-e399

8. Chen H, Wu J, Zhang Z, Tang Y, Li X, Liu S et al (2018) Association Between BRCA Status and Triple-Negative Breast Cancer: A MetaAnalysis. Front Pharmacol 9:909

9. King MC, Marks JH, Mandell JB, New York Breast Cancer Study Group (2003) Breast and ovarian cancer risks due to inherited mutations in BRCA1 and BRCA2. Science 302:643-646

10. Stevens KN, Vachon CM, Couch FJ (2013) Genetic susceptibility to triple-negative breast cancer. Cancer Res 73;2025-2030

11. Daly MB, Axilbund JE, Buys S, Crawford B, Farrell CD et al (2010) Genetic/familial high-risk assessment: breast and ovarian. J Natl Compr Canc Netw 8:562-594

12. National Comprehensive Cancer Network, NCCN Guidelines Version 5.2020. Invasive Breast Cancer. NCCN.org

13. Comen E, Davids M, Kirchhoff T, Hudis C, Offit K, Robson M (2011) Relative contributions of BRCA1 and BRCA2 mutations to "triplenegative" breast cancer in Ashkenazi Women. Breast Cancer Res Treat 129:185-190

14. Rosenthal E, Moyes K, Arnell C, Evans B, Wenstrup RJ (2015) Incidence of BRCA1 and BRCA2 non-founder mutations in patients of Ashkenazi Jewish ancestry. Breast Cancer Res Treat 149:223-227

15. Warner E, Foulkes W, Goodwin P, Meschino W, Blondal J, Paterson C et al (1999) Prevalence and penetrance of BRCA1 and BRCA2 gene mutations in unselected Ashkenazi Jewish women with breast cancer. J Natl Cancer Inst 91:1241-1247

16. Talhouet S, Peron J, Vuilleumier A, Friedlaender A, Viassolo V, Ayme A et al (2020) Clinical outcome of breast cancer in carriers of BRCA1 and BRCA2 mutations according to molecular subtypes. Sci Rep 10:7073

17. Levy-Lahad E, Catane R, Eisenberg S, Kaufman B, Hornreich G, Lishinsky E et al (1997) Founder BRCA1 and BRCA2 mutations in Ashkenazi Jews in Israel: frequency and differential penetrance in ovarian cancer and in breast-ovarian cancer families. Am J Hum Genet 60:1059-1067

18. Roa BB, Boyd AA, Volcik K, Richards CS (1996) Ashkenazi Jewish population frequencies for common mutations in BRCA1 and BRCA2. Nat Genet 14:185-187

19. Górski B, Jakubowska A, Huzarski T, Byrski T, Gronwald J, Grzybowska E et al (2004) A high proportion of founder BRCA1 mutations in Polish breast cancer families. Int J Cancer 110:683-686

20. Krajc M, Teugels E, Zgajnar J, Goelen G, Besic N, Novakovic S et al (2008) Five recurrent BRCA1/2 mutations are responsible for cancer predisposition in the majority of Slovenian breast cancer families. BMC Med Genetics 9:83

21. Johannesdottir G, Gudmundsson J, Bergthorsson JT, Arason A, Agnarsson BA, Eiriksdottir G et al (1996) High prevalence of the 999del5 mutation in icelandic breast and ovarian cancer patients. Cancer Res 56:3663-3665

22. Rajkumar T, Soumittra N, Nancy NK, Swaminathan R, Sridevi V, Shanta V (2003) BRCA1, BRCA2 and CHEK2 (1100 del C) germline mutations in hereditary breast and ovarian cancer families in South India. Asian Pac J Cancer Prev 4:203-208

23. Valarmathi MT, Sawhney M, Deo SS, Shukla NK, Das SN (2004) Novel germline mutations in the BRCA1 and BRCA2 genes in Indian breast and breast-ovarian cancer families. Hum Mutat 23:205

24. Saxena S, Chakraborty A, Kaushal M, Kotwal S, Bhatanager D, Mohil RS et al (2006) Contribution of germline BRCA1 and BRCA2 sequence alterations to breast cancer in Northern India. BMC Med Genetics 7:75 
25. Vaidyanathan K, Lakhotia S, Ravishankar HM, Tabassum U, Mukherjee G, Somasundaram K (2009) BRCA1 and BRCA2 germline mutation analysis among Indian women from south India: identification of four novel mutations and high-frequency occurrence of 185delAG mutation. J Biosci 34:415-422

26. Juwle A, Saranath D (2012) BRCA1/BRCA2 gene mutations/SNPs and BRCA1 haplotypes in early-onset breast cancer patients of Indian ethnicity. Med Oncol 29:3272-3281

27. Kumar BV, Lakhotia S, Ankathil R, Madhavan J, Jayaprakash PG, Nair MK et al (2002) Germline BRCA1 mutation analysis in Indian breast/ovarian cancer families. Cancer Biol Ther 1:18-21

28. Hedau S, Jain N, Husain SA, Mandal AK, Ray G, Shahid M et al (2004) Novel germline mutations in breast cancer susceptibility genes BRCA1, BRCA2 and p53 gene in breast cancer patients from India. Breast Cancer Res Treat 88:177-186

29. Hansa J, Kannan R, Ghosh SK (2012) Screening of 185DelAG, 1014DelGT and 3889DelAG BRCA1 mutations in breast cancer patients from North-East India. Asian Pac J Cancer Prev 13:5871-5874

30. Mullineaux LG, Castellano TM, Shaw J, Axell L, Wood ME, Diab S et al (2003) Identification of germline 185 delAG BRCA1 mutations in non-Jewish Americans of Spanish ancestry from the San Luis Valley. Colorado Cancer 98:597-602

31. Laitman Y, Feng BJ, Zamir IM, Weitzel JN, Duncan P, Port D et al (2013) Haplotype analysis of the 185delAG BRCA1 mutation in ethnically diverse populations. Eur J Hum Genet 21:212-216

32. Drost R, Dhillon KK, van der Gulden H, van der Heijden I, Brandsma I, Cruz C et al (2016) BRCA1185delAG tumors may acquire therapy resistance through expression of RING-less BRCA1. J Clin Invest 126:2903-2918

33. Gajalakshmi P, Natarajan TG, Selvi Rani D, Thangaraj K (2007) A novel BRCA1 mutation in an Indian family with hereditary breast/ovarian cancer. Breast Cancer Res Treat 101:3-6

34. Mehta A, Vasudevan S, Sharma SK, Kumar D, Panigrahi M, Suryavanshi M et al (2018) Germline BRCA1 and BRCA2 deleterious mutations and variants of unknown clinical significance associated with breast/ovarian cancer: a report from North India. Cancer Manag Res 10:6505-6516

35. Ahmad F, Natarajan S, Das BR (2020) Molecular Spectrum of Germline BRCA1 and BRCA2 Mutation in a Cohort of Indian Cancer Patients: A Report from Reference Laboratory. J Mol Genet Med 14:467

36. Geredeli C, Yasar N, Sakin A (2019) Germline Mutations in BRCA1 and BRCA2 in Breast Cancer Patients with High Genetic Risk in Turkish Population

37. Santonocito C, Rizza R, Paris I, Marchis L, Paolillo C, Tiberi G et al (2020) Spectrum of Germline BRCA1 and BRCA2 Variants Identified in 2351 Ovarian and Breast Cancer Patients Referring to a Reference Cancer Hospital of Rome. Cancers (Basel) 12:1286

38. Tihomirova L, Vaivade I, Fokina O, Peculis R, Mandrika I, Sinicka O et al (2014) BRCA1 gene-related hereditary susceptibility to breast and ovarian cancer in Latvia. Adv Med Sci 59:114-119

39. Lang GT, Shi JX, Hu X, Zhang CH, Shan L, Song CG et al (2017) The spectrum of BRCA mutations and characteristics of BRCAassociated breast cancers in China: Screening of 2,991 patients and 1,043 controls by next-generation sequencing. Int $\mathrm{J}$ Cancer 141:129-142

40. Thomassen M, Blanco A, Montagna M, Hansen TV, Pedersen IS, Gutiérrez-Enríquez S et al (2012) Characterization of BRCA1 and BRCA2 splicing variants: a collaborative report by ENIGMA consortium members. Breast Cancer Res Treat 132:1009-1023

41. Palmero El, Carraro DM, Alemar B, Moreira M, Ribeiro-Dos-Santos Â, Abe-Sandes K et al (2018) The germline mutational landscape of BRCA1 and BRCA2 in Brazil. Sci Rep 8:9188

42. Pal T, Permuth-Wey J, Holtje T, Sutphen R (2004) BRCA1 and BRCA2 mutations in a study of African American breast cancer patients. Cancer Epidemiol Biomarkers Prev 13:1794-1799

43. Lindor NM, Guidugli L, Wang X, Vallée MP, Monteiro AN, Tavtigian S et al (2012) A review of a multifactorial probability-based model for classification of BRCA1 and BRCA2 variants of uncertain significance (VUS). Hum Mutat 33:8-21

44. Kadri M, Patel KM, Bhargava PA, Shah FD, Badgujar NV, Tarapara BV et al (2021) Mutational Landscape for Indian Hereditary Breast and Ovarian Cancer Cohort Suggests Need for Identifying Population Specific Genes and Biomarkers for Screening. Front Oncol 10:568786

45. Seifert BA, O'Daniel JM, Amin K, Marchuk DS, Patel NM, Parker JS et al (2016) Germline Analysis from Tumor- Germline Sequencing Dyads to Identify Clinically Actionable Secondary Findings. Clin Cancer Res 22:4087-4094

46. Artioli G, Giannone G, Valabrega G, Maggiorotto F, Genta S, Pignata S et al (2021) Characteristics and outcome of BRCA mutated epithelial ovarian cancer patients in Italy: A retrospective multicenter study (MITO 21). Gynecol Oncol S0090-8258(21)00324-3 
47. Liu Y, Wang H, Wang X, Liu J, Li J, Wang X et al (2021) Prevalence and reclassification of BRCA1 and BRCA2 variants in a large, unselected Chinese Han breast cancer cohort. J Hematol Oncol 14:18

48. Cherbal F, Bakour R, Adane S, Boualga K, Benais-Pont G, Maillet P (2010) BRCA1 and BRCA2 germline mutations screening in Algerian breast/ovarian cancer families. Dis Markers 28:377-384

49. Jakimovska M, Maleva Kostovska I, Popovska-Jankovic K, Kubelka-Sabit K, Karadjozov M, Stojanovska L et al (2018) BRCA1 and BRCA2 germline variants in breast cancer patients from the Republic of Macedonia. Breast Cancer Res Treat 168:745-753

50. Heidemann S, Fischer C, Engel C, Fischer B, Harder L, Schlegelberger B et al (2012) Double heterozygosity for mutations in BRCA1 and BRCA2 in German breast cancer patients: implications on test strategies and clinical management. Breast Cancer Res Treat 134:1229-1239

51. Zuntini R, Ferrari S, Bonora E, Buscherini F, Bertonazzi B, Grippa M et al (2018) Dealing With BRCA1/2 Unclassified Variants in a Cancer Genetics Clinic: Does Cosegregation Analysis Help? Front Genet 9:378

52. Thirthagiri E, Lee SY, Kang P, Lee DS, Toh GT, Selamat S et al (2008) Evaluation of BRCA1 and BRCA2 mutations and risk-prediction models in a typical Asian country (Malaysia) with a relatively low incidence of breast cancer. Breast Cancer Res 10:R59

53. Borg A, Haile RW, Malone KE, Capanu M, Diep A, Törngren T et al (2010) Characterization of BRCA1 and BRCA2 deleterious mutations and variants of unknown clinical significance in unilateral and bilateral breast cancer: the WECARE study. Hum Mutat 31:E1200E1240

54. Rashid MU, Muhammad N, Bajwa S, Faisal S, Tahseen M, Bermejo JL et al (2016) High prevalence and predominance of BRCA1 germline mutations in Pakistani triple-negative breast cancer patients. BMC Cancer 16(1):673

55. Park HS, Park SJ, Kim JY, Kim S, Ryu J, Sohn J et al (2017) Next-generation sequencing of BRCA1/2 in breast cancer patients: potential effects on clinical decision-making using rapid, high-accuracy genetic results. Ann Surg Treat Res 92:331-339

\section{Figures}

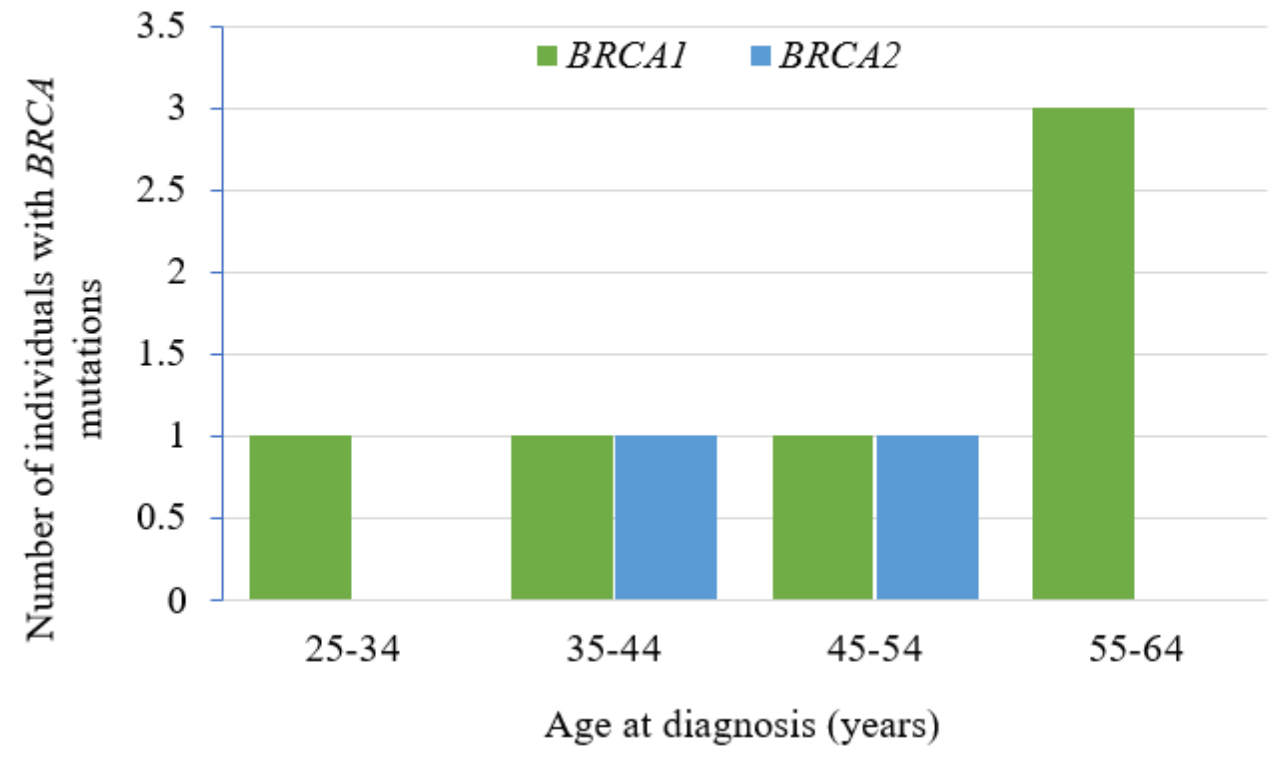

\section{Figure 1}

Age distribution of TNBC patients with BRCA mutations 